\title{
Merit-based recruitment: the key to effective public administration in Bangladesh
}

\author{
Md. Shiplu Zaman* \\ A JDS Fellow at Graduates School of Economics, Yamaguchi University, Yamaguchi, Japan \\ Email: s_z_03@yahoo.com, Mobile: +81-080-6269-1696
}

Doi:10.5296/ jpag.v5i3.8216 URL: http://dx.doi.org/10.5296/ jpag.v5i3.8216

\begin{abstract}
Bangladesh Civil Service (BCS) is like the nucleus of country's overall development. Brilliant graduates wish to join BCS and contribute to the prosperity of the nation. However, it is not that easy to join BCS for all meritorious graduates. Due to quota or preserved post in greater part of BCS, they are denied from the service of the nation. However, Bangladesh needs an effective public administration to turn up her long-term vision to be a middle-income country by 2021. Nonetheless, for an effective and dynamic public administration, recruitment of talented, hard working and committed personnel are essential. In this perspective, the study intends to evaluate the present recruitment system of BCS, analyzes its problems, and tries to find out the possible solution. In addition, it tries to know the idea and observation of present and future civil servants regarding present recruitment system and overall BCS. It collects primary data from the respondents before analyzing and providing some policy recommendations. It also compares and contrasts, why BCS needs merit not quota. Finally, the study proposes a model for Merit-based Recruitment in BCS with some assumptions.
\end{abstract}

Keywords: Merit, Recruitment, Civil Service, effective, public administration

* Address in Bangladesh: Senior Information Officer, Ministry of Information, Government of Bangladesh. Home address - 38 Gour Sundor Rai Lane, Chadni Ghat, Lalbag, Dhaka-1211, Bangladesh, mobile: +880-1911-201270, +880-1550-552202. 


\section{Introduction}

Civil Service System (CSS) can be seen as a concept of the institution and an organization and includes some values to guide policy making and rules of HRM (Raadschelders; Tonen \& Meer, (Eds.) 2007). However, today's CSS is not a new invention. It is the heart of the theory of public administration. Roots and shapes of the CSS are changing by the Dichotomy Theory of Woodrow Wilson, "Bureaucracy Theory of Max Weber, Scientific Management Theory of F W Taylor” (Rabbi \& Saber, 2012). The CSS also follows Henry Fayol's 14 Principles of Management. The Bangladesh Civil Service (BCS) is no difference; it also follows the basic idea of the bureaucracy and public administration.

The functions and working areas of the civil service have been changing day by day because of the increase in awareness level and education of the citizen. The role of civil society, free flow of information, a vital role of media, use of Information Technology (IT) and other factors also influencing the CSS. Peoples' expectations from civil servants are going to touch the Mount Everest. Also, a new system of "managerialism, New Public Management, entrepreneurial government" (Rabbi \& Saber, 2012), are coming into the action and making things more difficult for civil servants. CSS, nowadays, considers citizen as a customer. However, these changes, and approaches demand civil service to be more efficient and professional. Undoubtedly, BCS has a big role to play to confirm the proper Public Financial Management (PFM), resource utilization, economic development and many such things in Bangladesh. Nevertheless, in doing so, the first element requires, is a meritorious and dynamic Civil Service. However, it will be possible when recruitment process of BCS fully follow the merit-based system.

The present recruitment system in BCS does not follow completely the merit principle rather lead by the quota system. In this perspective, this study attempts to evaluate the present recruitment system and its problems. Taking the idea from the present and future civil employee, it tries to find out the possible solution of the problem. The scope of the study covers the direct recruiting process of first class officers who join the service by BCS examination. In addition, the study makes an effort to critically compare why BCS needs merit and why not quota. Finally, it proposed a model for merit-based recruitment in BCS with some assumptions.

\section{Background and Importance of the Study}

Bangladesh is an emerging economy nowadays, in the world. She has prosper and earned a lot despite many things yet to achieved. However, the government of Bangladesh along with the compatriots is working hard to take the country to the zenith of development. Peoples of Bangladesh are very active, patriotic, and determined. They can make anything happen and can bring the positive changes for the country. As they did in the Liberation War in 1971, fought against the brutal attack of armed forces of the then West Pakistan to snatch away our victory at a cost of their supreme sacrifices. The only thing Bangladesh needs is to support the citizen showing the right path of development, the rest will come automatically in its consequences. 
In this milieu, the important question is who can take the mass to the right ways; who can create examples for fellow citizens. The answer may be political leaders or opinion leaders from the society, however, politician came to power for a certain period. On the contrary, the public officials hold their positions and power for a longer time. They are at the suitable position to motivate and work with the people to contribute for nation building. Moreover, Bangladesh is dreaming to be a middle-income country by 2021, she has a long-term vision named "Vision-2021" along with Millennium Development Goals (MDGs). To materialize this vision and achieve MDGs, civil service of Bangladesh has a pivotal role. The bottom line here is, Bangladesh must have a meritorious, efficient, honest and dedicated public administration.

Conversely, the history says that the civil service of Bangladesh is not fully meritocratic, as a result it lacks of dynamism and efficacy. Since the birth of the nation, Bangladesh by the Constitution is favoring the backward section of the society in its service. People of so-called backward section have 55\% preserved seat in the service of the state and the rest $45 \%$ is open for competition. Notwithstanding, after 44 years of independence and at the age of globalization when light of education and touch of development reaches all over the country, such high degree of quota in public service is not pragmatic. Consequently, low caliber people are coming to the sensitive job at the state level and resulting under performances. Therefore, a fully merit-based recruitment system is urgent requirement for Bangladesh. Nonetheless, many attempts to change the system took place but the output is near to zero due to many unanswered reasons. The result of failure to change has a severe effect on our public administration in the end as Mohammad Mohabbat Khan (2009) rightly says,

The entire public service is in a state of crisis. It is characterized by a rigid structure, low productivity, overarching reach, lack of delegation of authority, recruitment not totally based on merit, inappropriate training and not need-based, promotion not linked with performance, irrational transfer, constant inter-cadre feud, pay not-linked to performance and productivity and low morale (Khan, 2009, p. 112).

The importance of merit-based recruitment not only for public service but also for all services is beyond description. The Civil service is vital though not the single factor to ensure good governance in any country. However, that factor must be qualified and productive enough to face the unforeseen challenges of the future. A quality and efficient civil service is not byproducts of training or experience rather it is the output of a combined effort of merit-based recruitment, timely and need-based training and congenial working environment. Nonetheless, the most important thing is to find the quality and able human resources who can bring a positive result for their nation. Civil service termed as the backbone, or executive arm of government and effectiveness of the service has a close relation to meritocratic recruitment and promotion of the civil servants (Yesmin, N., 2010).

Bangladesh Civil Service (BCS) is the most prestigious and highly valued service in the country, but the service does not totally follow the meritocratic recruitment or promotion system. Experts and researchers manifest many problems and limitations with BCS. In this regards, Mohammad Mohabbat Khan (2009) says, 


\section{Macrothink}

The civil service in Bangladesh has inherited many of the characteristics of the colonial bureaucracies of British India and Pakistan. The bureaucratic culture is in many respects alien and not suited to the needs and aspirations of citizens. The bureaucratic culture in Bangladesh has been influenced to a considerable extent both by the structural rigidities of an inherited colonial system of administration and the consequent behavioral patterns of the bureaucrats (Khan, 2009, p. 110).

Therefore, BCS needs changes and reforms that can bring in to service the brilliant and enthusiastic citizen who can create a new bureaucratic culture, suitable and affable for country's development and growth.

Pan Suk Kim and Mobasser Monem (2008) rightly assert,

Bangladesh needs a civil service of high quality and integrity for mobilizing and utilizing its domestic resources. This requires innovative ideas, serious effort, dedication, and efficiency. It can be argued that public administration in Bangladesh is rather gradually drifting away from these desired qualities. Urgent reforms are, therefore, necessary so that these qualities can be restored and fostered (Kim \& Monem, 2009, p. 2).

A similar statement comes from the country director of Department for International Development (DFID), David Wood with the press at a conference named, "Asia-2015: Promoting Growth, Ending Poverty". He concludes that Bangladesh's civil servants are incapable of implementing foreign aided projects, and Bangladesh needs to reduce corruption and increase the capacity of civil servants for proper utilization of foreign aid (Haque, 2006).

A country's civil service needs to be capable enough to deal with both the external and internal pressure and consider all the factors coming into the process. Sumedh Rao (2013) cites Schiavo-Campo and Sundaram (2001) in GSDRC's Topic Guide to explain the importance of civil service as below (bullet points),

- An efficient civil service is important for ensuring good governance

- Skilled civil service is required to provide quality public service to the mass,

- A capable civil service is must for implementation of economic and development policy

- A competent civil service can properly manage public expenditure and revenue

- To maintain fiscal sustainability civil service can play a vital role

- Institutional development through interaction with an external organization is possible if a country have dynamic public officials (Rao, S. 2013, p.5).

Besides, the civil service of a country has to play a pivotal role in catching up industrialization, globalization and international negotiation to gain maximum benefits for the home country. For this, they need to develop new organizational and communication skill to cope up with the pace. In fact, the civil service of a country is like an image that shows the level of development and organizational ability of a country. Therefore, a meritorious civil 
service has no second alternative in a government system.

Many studies on this issue so far recommended many changes to the policy makers, albeit implementation is very low. Most of the researches were based on secondary data and over all administrative reform of Bangladesh. On the other side, this study depends on the primary data collected from the present and future civil servants of Bangladesh. The study analyzes why merit and why not quota is necessary in civil service. Knowing the idea and view of target people, the study tried to develop a model for merit-based recruitment in civil service of Bangladesh. In this regard, this study is unique from other similar studies.

\section{Conceptual Framework}

\subsection{Merit:}

Defining merit is difficult, as definition of merit differs with time and situation. If we assume a society, where there is no problem, an abundance of resources, no unemployment, no social discrimination and such other things, then we need not the concept of merit. Because, merit comes into action when there is competition, and we have to find out qualified people who are capable of accomplishing some particular job better than others do. Those qualified people are meritorious and fit for that particular job. Again, if there is no unemployment, everyone gets a job, even if, among him or her to find the best one, merit is essential. Therefore, sometimes merit accepts inequality (Madan, 2007).

Merit may be defined as

Ability of an individual to perform activities effectively and efficiently

$>$ Competency to add value to the organization

$>$ Equal value for good manners

$>$ Superior to others by some exceptional qualities

However, different authors describe merit differently, and they provided several theories of merit. It is termed by Mc Crudden as, someone's ability and qualities that bring reward from society (Mc Crudden, 1998). Merit is completely a personal attribute and affects society as a social phenomenon. Merit employs best man in a particular job (McCourt, 2007).

Reynolds, J., \& Xian, H. (2014), cites Michael Young in an equation and shows merit as,

$$
\text { Merit = Intellectual Quality (IQ) + Effort (Reynolds; Xian, 2014). }
$$

If a person can use his/her intellectual ability and put the best efforts to complete a particular job, then he/she is said to be meritorious. It means merit makes people successful as par their ability and talent (Alvardo, 2010).

\subsection{Recruitment:}

Recruitment is like the foundation of a structure. If the basement can ensure quality and standard, an organization can produce quality outcomes and reach quickly to their cherished goals. Recruitment refers to the process of inviting people who have necessary skills for a job. 


\section{Macrothink}

The process starts with asking candidates, but it's after effect continues over the life of an organization (Werther \& Davis, 1996). "The recruitment process includes five related stages as- planning, strategy development, searching, screening and evaluation and control" (Aswathappa, 2005).

The Government is the largest organization and highest recruiter in a country. They recruit people for a longer time and government employees are lifelong human resources. There are some legal framework, rules-regulations, policies and political commitment while recruiting for a government job. If the government can hire the best people in terms of ability, talent, intellectual ability, knowledge, efforts and so forth, then those recruits can serve the fellow citizens and states to their full capacity. By recruitment this write up mean to say the selection process of public employees of Bangladesh.

\subsection{Civil Service:}

A single definition of Civil Service (CS) does not fit fully in all the countries all the time though the essential elements remain the same.

Many experts illustrate public service in their style and words but point out almost the same inner meanings or theme as, Civil service refers to,

- "Essential part of governance” (Jahan, M. 2012)

- "Permanent administrative arm of government" (Rao, S. 2013)

- "Neutral instrument of government" (Obaidullah, 1999)

- “A legal construction” (Cardona, F. 2002)

- "Incredible institution with integrity, honesty, impartiality, and objectivity" (Daugher, 2014)

If we blend all these terms to find a definition we can write, the civil service is a legal, neutral and permanent organ of government. CS is essential for delivery of services to mass with the utmost integrity, honesty, and objectivity. However, here in this paper CS means Bangladesh Civil Service.

\subsection{Civil Servant:}

Civil servants are like the engineers who can drive best the wheel of public administration to ensure sustainable development and prosperity of a country. Nonetheless, to do this, they require the sense of patriotism, willingness to serve the nation, efficiency and necessary skills. They have something that separates them from general people. That is why; civil servants of a country get special respect and attention from their respective society and even in the international arena.

R K Pruthi (2005) asserts,

A civil servant is required to tender advice in the formulation of public policy on the basis of an honest assessment of the best strategy for attaining the goals desired by means of the 
resources available to state (Pruthi, 2005, p. 47).

However, Hamid Ansari ${ }^{\mathrm{i}}$ defines civil servants as the eyes, ears, tongues and hands of government by which government sees, hears, speaks and touches (Chalam, 2014). On the other side, in many central and eastern European countries civil servants are those people who hold authority in policy-making and drafting and implementation of legislation (Cardona, F. 2002).

In this manuscript, civil servants refer to the employees working for the Government of the Peoples Republic of Bangladesh. According to Ministry of Public Administration, by the year 2013, total number of civil servants in Bangladesh is 11, 94,449 (MOPA, 2013).

\section{Literature Review}

Bangladesh Civil Service, BCS is composed of four levels of employees as,

Class- $1+$ Class- 2 + Class- 3 +Class- 4 = BCS.

The officials are posted in various ministries and departments and rotated as required. The Class -1 employee who pass the BCS are called cadre ${ }^{\text {ii }}$ officers. The quota system dominates the recruitment of cadre official as $55 \%$ of them are selected by quota. The quota system is like a curse to the brilliant and bright graduates who desire to join the BCS. Many authors explained their concern time to time in their writings; however, change is very little.

Dr. Kamal Siddiqui (1996) in his book 'Toward Good Governance in Bangladesh', provides several suggestions for amendments to the existing quota rules like,

- "No quota for District and Freedom Fighters

- Merit should fill at least $65 \%$ BCS posts

- Increase women quota to $30 \%$

- 5\% quota for tribal will continue but within the quota, positive discrimination should be made for most depressed tribes

- Finally, this system needs to review after every five years" (Siddiqui, K. 1996).

The researcher does agree, Dr. Kamal with his suggestion of no quota for freedom fighters and their children. Also, his recommendation for 5\%-reserved seats for tribal people is important. However, reviewing the system every five years is a time worthy and essential demand from the retired senior civil servant. On the contrary, the researcher does not think women quota needs to rise further rather reduce.

M. Abdul Wahhab (2009), opines the same. He discusses the fairness of policy with equality in job opportunity and efficiency. He concludes that the BCS recruitment policy in Bangladesh is not sound because it does not stress on merit rather quota. In addition, he suggests some recommendations in his paper as the reformation of BPSC, abolition of the quota system, consideration of educational background and result, stop Ad Hoc appointments and so on. Moreover, quota system never followed transparency; he sought, as we cannot get 
any adequate information about the quota applied. Wahhab added that cushion was necessary for the advancement of backward sections in the society of Bangladesh, but for a particular period. As a result, the long-term negative impact is being evident in BCS with the entry of relatively mediocre caliber people. However, he advocates 5\% quota for tribal people except the Chakmas, who are more educated and more developed than any other ethnic groups in Bangladesh (Wahhab, 2009).

In another study, James E. Rauch and Peter B. Evans (2000) argue that there are many factors readily identifiable that constitute the essential ingredients of effective state bureaucracies and should help to predict ratings of bureaucratic performance. Those are competitive salaries, internal promotion and career stability, and meritocratic recruitment. After collecting data from 35 less developed countries, they showed the positive correlation between meritocratic recruitment and bureaucratic performance. However, the importance of competitive salaries and internal promotion and career stability could not be clearly established (Rauch \& Evans, 2000).

Shamsul Huq Zahid (2013) mentions that an extensive study carried out by Dr. Akbar Ali Khan and Kazi Rakibuddin Ahmed on the quota system for civil service recruitment in Bangladesh in 2008. The report finds that the recruitment of only $45 \%$ candidates of BCS examinations based on merit is unconstitutional. The researchers also think that there is no legal basis of quota for the freedom fighters. To them, the quota would be logical if freedom fighters were backward among the citizens since the country's constitutions permit quota only in the case of backward sections of citizens. They highlight how the BPSC was failing to fill up the reserved quotas owing to the lack of fit candidates who could not qualify the four stages of the recruitment process. As a result, posts against quotas remain vacant while hundreds of the meritorious youth fail to secure a government job. The duo suggests that the government might abolish all quotas on the ground that those had not served any useful role in improving the lot of the preferred groups. Some of the quotas were not consistent with the provisions of the Constitution of the Republic (Zahid, 2013).

However, Ripon Kumar Biswas (2013) stated BCS as the real wheel of country's administration and raised many questions. Terming the irregularities in BCS examination as hindrances for getting genuine administrators to serve the country, the article suggests recruiting the best people that the country needs. He suggests BPSC to expand its horizon to find skilled workforce (Biswas, 2013). The researcher thinks the article clearly highlights the problems of the present recruitment system of BCS. It demands a right reform move. Indeed, a reform is an utmost need for the recruitment process and overall civil service system in Bangladesh. Even if, reform is not easy to come by, it is very difficult to implement. However, it is better than revolution (A. A. Khan, 2010) (Kim \& Monem, 2009). Nevertheless, there were many attempts to reform the BCS system but produced a little outcome.

On this context, Pan Suk Kim and Mobasser Monem (2009), examine BCS and try to find out the scope for further development. They focus on the structural dimensions of BCS and reform initiative took so far and the reasons why those schemes failed in Bangladesh. They 
term BCS as, "over centralized, unaccountable, inefficient, underpaid, coercive and non-transparent". The writers propose to build consensus, change management strategy, positive political will, and enormous effort that can turn the reform initiatives into reality (Kim \& Monem, 2009). A similar sort of explanation and opinion came from Md. Fazle Rabbi and Sharif N As-Saber (2012). Mentioning several attempts of change, they tried to find out the reasons for the failure of those initiatives. (Rabbi \& Saber, 2012).

However, Abu Elias Sarkar (2004) clearly mentions the reasons for the failure of administrative reform in our country. He argues that some factors tried to shape up the reform efforts and consequently could not succeed. Such factors are a lack of political commitment; the limited capacity of government; bureaucratic resistance; factionalism within the public service; corruption; politicization and corruption and so on (Sarkar, 2004).

\section{Methodology}

The study uses primary data randomly collected from Present Civil Servant (CS) and Prospective Civil Servant ${ }^{\text {iii }}$ (PCS) through a standard questionnaire comprised of close-ended questions. The questionnaire includes various aspects of recruitment, promotion and reform of BCS. Some questions in the questionnaire contain multiple answers and the respondent answered accordingly. All the respondents are graduated; they can understand how to fill the questionnaire. Hence, they filled by themselves; nonetheless, researcher guided them as well.

The sample size was 150 in total, 70 for CS and 80 for PCS. Data collected from several government offices and training institutions and from different universities. After data collection, the study uses SPSS and Ms-Excel for data entry and quantitative analysis.

\section{Research Question}

1. Should merit be used as the main criteria in recruitment and selection process of BCS?

2. Is merit-based recruitment necessary for BCS?

3. Can merit-based recruitment in BCS bring bright performances in the field of public administration of Bangladesh?

\section{Present Recruitment system}

The legal base of Bangladesh Civil Service is developed in the Constitution of Bangladesh. However, some other rules and regulations framed and shaped up the legal framework of BCS. In the Constitution Bangladesh, Article 29 ensures the right to equal opportunity for people to enter into a public job (Government of Bangladesh, 2014). As mentioned earlier, the study focuses on the direct recruitment of BCS cadres only; this section will discuss the present recruitment process of BCS cadres. The process takes place in different stages and requires a long time. Mainly Ministry of Public Administration (MOPA) and Bangladesh Public Service Commission (BPSC) deal with the process though other organizations help actively. 
1. First, MOPA sends requisition letter to all concerned ministries, asking to inform their vacant posts. After collecting the requisitions from all ministries and departments, MOPA along with its own demand, asks BPSC to recruit such number of officers and recommend for an appointment.

2. Then, getting the demand, BPSC publishes the notification in daily newspapers, takes examinations and takes necessary measures for a medical checkup by a board. At last, recommends the cadre wise recruited candidates to MOPA.

3. MOPA takes the initiative to verify the police records of the recruits with the help of Home Ministry, and gets the approval of the President and finally issues the letter of appointments.

However, to decide the age, education, other qualification and experience, the Bangladesh Civil Service (Age, qualification and examination for direct recruitment) Rules 2014 has to follow.

We can see the process as a flow-chart as given below,

Figure 1: Flowchart of the recruitment process of BCS

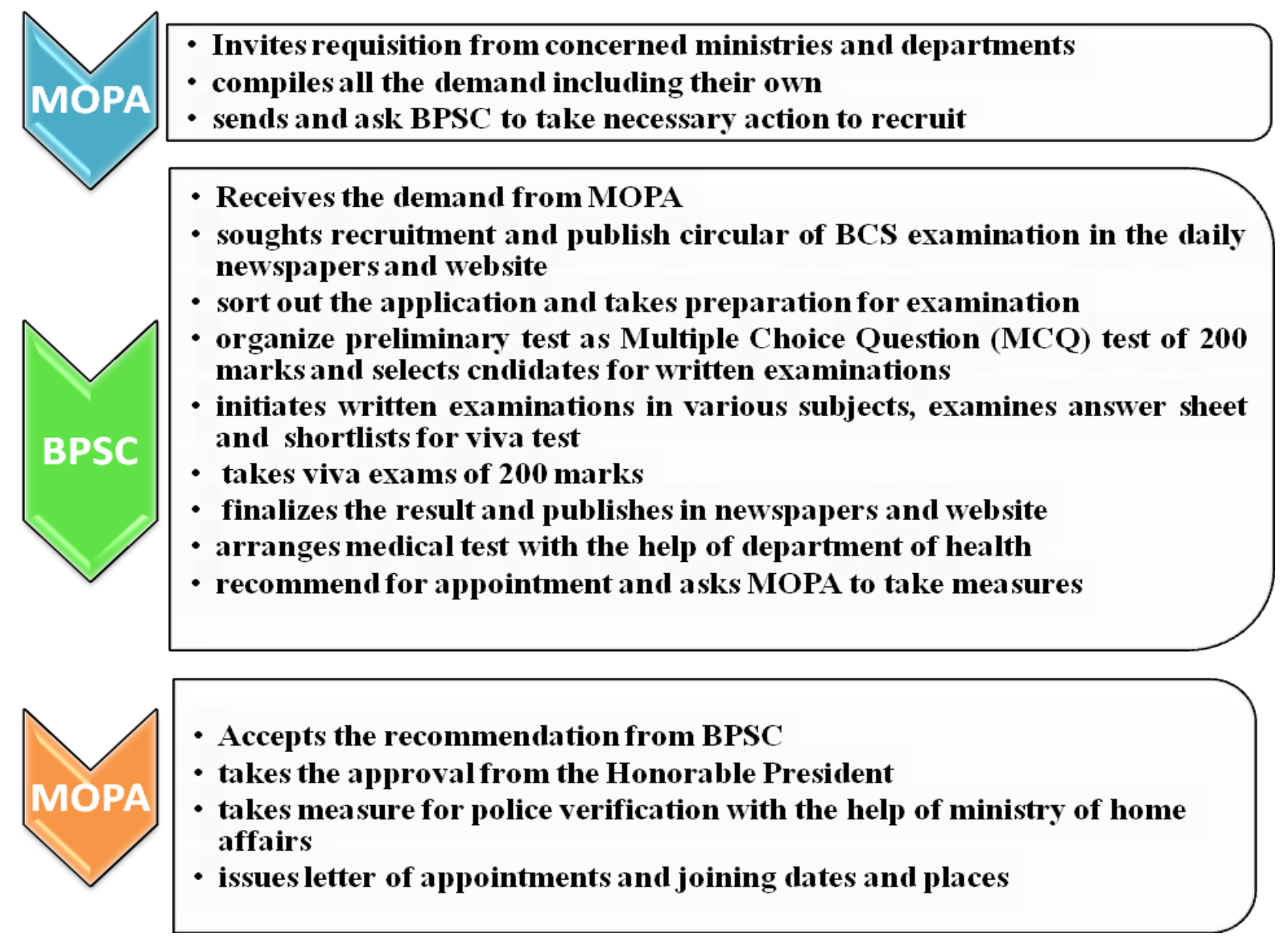

Source: Researcher prepared 


\section{Macrothink}

As Figure 1, shows the chronological procedure of recruiting BCS cadre officials. All the candidates recruited and selected join at the place and time as written in the appointment letter. They need to declare the amount of assets they have at the time of joining and sign the bond as per rules.

\subsection{Required qualification:}

To apply and attend the BCS examination a competitor must have certain qualities. The general principles and requirements are given below,

\subsubsection{General Principle}

The general principles of Direct Recruitment by BCS are-

- need recommendation from BPSC

- candidate must be Bangladeshi domicile

- cannot marry or promise to marry a foreigner

- declared physically fit by government health department

- have to pass police verification

- apply through proper channel

- complete all formalities mentioned by BPSC.

\subsubsection{Requirements}

- Education - at least a 4 years Honors course

- Age - in general 30 years, for freedom fighters children 32 years, for ethnic people in BCS (general and technical education), BCS (Health) service 32 years

- Probation period - two years for direct recruitment

- Job confirmation - must complete probation period satisfactorily and all foundation training and pass the required examination set by government.

\subsection{Problems with present recruitment system:}

Present recruitment system of BCS has some problems that required solution. Many studies suggest that BCS is losing its attractiveness due to these problems, and if BCS needs to attract meritorious candidates then it must be fair, competitive and time worthy (Jahan, M. 2012).

First, the recruitment process is a time-consuming and costly endeavor. It is a lengthy process. Sometimes the process takes more than one year. After analyzing the BPSC annual report 2012 and 2013 the study finds the time taken for various BCS examinations as furnish in Table, 
Table 1: Time consumed by a BCS examination

\begin{tabular}{|c|c|c|c|c|}
\hline $\begin{array}{l}\text { Batch of BCS } \\
\text { examination }\end{array}$ & $\begin{array}{l}\text { Start date } \\
\text { (Requisition) }\end{array}$ & $\begin{array}{l}\text { Finish } \\
\text { (VIVA) }\end{array}$ & $\begin{array}{l}\text { Time } \\
\text { needs }\end{array}$ & Average time needs \\
\hline $31^{\text {st }} \mathrm{BCS}$ & $16-01-2011$ & 23-04-2012 & 462 days & \multirow{3}{*}{$\begin{array}{l}477 \text { days }= \\
\text { One year three } \\
\text { months and } 22 \text { days }\end{array}$} \\
\hline $32^{\text {nd }} \mathrm{BCS}$ & 19-10-2011 & 28-11-2012 & 404 days & \\
\hline $33^{\text {rd }} \mathrm{BCS}$ & $15-02-2012$ & 09-09-2013 & 565 days & \\
\hline
\end{tabular}

Source: Researcher prepared from BPSC Annual Report 2012 \& 2013.

The table 1 shows that the average time requires completing a BCS recruitment process is more than 1.25 years. After that, six months more may need to publish the total result, medical test, police verification, and appointment.

Second, the study thinks that the evaluation system and course outline of BCS examination are not appropriate. In the preliminary test, $200 \mathrm{MCQ}$ types of questions are set, and candidates have to answer them in an OMR form within 2 hours. The researcher believes it is unfair to justify one's ability and merit only by 200 multiple-choice questions. Consequently, the shortlisted candidates sit for detail written examination. This exam cannot verify one's creativity, writing and analytical ability, and knowledge depth perfectly. However, many guidebooks are in the market specially prepare for BCS exam; candidates depends on memorizing to get a good score (Jahan, 2006). Therefore, who is truly meritorious is difficult to find out. The Third problem is not considering the educational background in BCS recruitment. A student may have the good educational record all through the life, but it is not considered in the result of BCS examination. That person may not do well in BCS exam for many unavoidable reasons rather have good scores through entire educational life.

The Fourth constraint is the consequence of the third problem that is a lack of specialization in the recruitment process. For an example, the country invests huge money to prepare Doctors and Engineers in the higher level of education. Nevertheless, many of them come to join BCS, and their choice is not their field rather some lucrative service like foreign affairs or custom. Consequently, the country lost their professional service; however, they can do well in another field as well. Even so, some specialization can be ensured in BCS, and that can give the fellow citizens a better and specialized service. The Fifth and most crucial limitation lie with the quota system, which is very complex and difficult to understand. No candidates can understand the system while applying for the BCS and even a civil servant does not know it very well. Nowadays, people are frequently migrating from one place to another. One may take birth in an underdeveloped region but living and growing up in a developed area. However, while applying for BCS, that person is getting advantages of his/her origin in the quota system. Thus, the intention and spirit of quota is diminishing. Moreover, experts and researchers opine that present quota system inspires corruption and political interference as no clear information regarding quota in BCS are public so far. 
Nevertheless, researchers, civil society, media and former bureaucrats always question quota for different groups of freedom fighters and their children and ethnic people. Due to the quota system, low caliber candidates get a chance to the important cadre service like administration, foreign affairs, police and so on. As a result, it hampers the quality service delivery to the mass people.

\subsection{Challenges of the present system:}

The study thinks that there are many challenges for the present recruitment system of BCS. Those challenges are like below,

1. Uphold the image of BCS with a free, fair and simple system of recruitment and find out the true brilliant for the service of the nation

2. Stop the leakage of questions forever and punish the guilty that no one can dare to do this again

3. Meritorious students are averting from BCS and going to private service or serving the foreign companies. Therefore, we need to revert them to BCS and stop the brain drain providing them worthwhile benefits

4. Considering the educational background in the BCS recruitment system is another challenge

5. Change the course outline of BCS exam in such a way that can identify the truly brilliant people, their analytical ability, and innovativeness

6. Most importantly, change the quota system. Develop a meritocratic system that welcome brilliant people to come to BCS by an open and competitive examination

7. Stop the corruption and political interferences in BCS recruitment process and

8. Make the BPSC a neutral and strong organization that can act as the factory of a good administrator for the country.

\section{Why not Quota}

The quota is frustrating and demoralizing for the true merit. Quota cannot continue for perpetuity, it should have some ending point. Otherwise, it is misused in favor of politics and interested groups. Quota resists the country in getting the quality service of brilliant graduates who could better serve the nation than those recruited based on quota. As a result, the new generation is averting from civil service rather they like to join in a private job that provide more financial and fringe benefits than that of government service.

If quota dominates in recruitment of civil servants, it would demoralize qualified graduates. Consequently, they would be frustrated and go astray. Meanwhile, country will denied from their contribution and because of brain drain, qualified human resource would go to the private and international organization. On the other part, quota would recruit under-qualified personnel in public administration. It would need more investment for educating, training and make them adapt to administrative culture. However, they would produce poor performances 


\section{Macrothink}

and compete for promotion and other benefits with the officers join based on merit. In that process, political intervention on administration and corruption would go high. The final effect is negative impact on country's growth and development.

The intention of quota is to ensure equal rights and reduce discrimination in BCS, but the application of quota has built-in discrimination as described in the Box 1 below.

\section{Box 1: Quota Distribution \& Discrimination: An Example}

In another way, the study analyzes the combined merit list of 24th BCS general cadres produced by BPSC and finds 733 officers from 12 cadres there. For an instance, a random number say 404 is selected from the list. An official, who is in 404th position, gets information cadre, and he is the first in his cadre. Obviously, he comes by merit and information cadre was not his first choice. However, the irony is that, after him means under 404th position, official recruited are,

- 136 in Administration Cadre

- 98 in Police Cadre

- 2 in Foreign Affairs Cadre

- 2 in Custom and Excise Cadre

- 11 in Tax Cadre and

- 4 in Audit Cadre

Normally these cadres are valued more and perceptibly, candidates choose these cadres before information. Consequently, the person in the 404th position is a victim of the quota system. He deserves a better cadre that the less qualified than him got staying below him. These officials will not only get swift promotion but also better opportunities than number 404 will get. In this way, the quota is hurting the mindset of an employee and frustrating them. Therefore, quality service is not possible either to that officer due to dissatisfaction or by officers below him because of lack of quality. Therefore, it creates another type of discrimination.

Source: Researcher prepared

Moreover, using quota is not productive in BCS because quota is not totally utilized due to lack of qualified candidates who cannot pass the examinations. In every BCS, many posts remain vacant, and quota system does not allow filling in those posts by merit. As a result, administrative functions hampered and became less productive.

The study analyzes the Annual Report of BPSC of 2012 and 2013 and finds, 


\section{Macrothink \\ Journal of Public Administration and Governance \\ ISSN 2161-7104 \\ 2015, Vol. 5, No. 3}

Table 2: Utilization of quotas in various BCS examinations

\begin{tabular}{|c|c|c|c|c|c|}
\hline $\begin{array}{l}\text { BCS } \\
\text { batch }\end{array}$ & Group & $\begin{array}{l}\text { 1.Quota } \\
\text { preserved }\end{array}$ & $\begin{array}{l}\text { 2.BPSC recommend for } \\
\text { appointments (after } \\
\text { exam) }\end{array}$ & $\begin{array}{l}\text { 3. Vacant } \\
\text { posts }\end{array}$ & $\begin{array}{l}\text { 4.Percentage } \\
(3 / 1 * 100=4)\end{array}$ \\
\hline $31^{\text {st }}$ & $\begin{array}{l}\text { Freedom } \\
\text { Fighters }\end{array}$ & 865 & 322 & 543 & $62.77 \%$ \\
\hline \multirow{4}{*}{$\begin{array}{l}\text { Total } \\
\text { number of } \\
\text { Quota is } \\
55 \% \text { of } \\
\text { Vacant } \\
\text { Posts } \\
2909\end{array}$} & Women & 296 & 237 & 59 & $19.93 \%$ \\
\hline & Tribal & 142 & 16 & 126 & $88.73 \%$ \\
\hline & District & 283 & 248 & 35 & $12.36 \%$ \\
\hline & Disable $^{\mathrm{iv}}$ & ------ & 2 & ----- & ----- \\
\hline & Total & 1586 & 825 & 761 & $47.98 \%$ \\
\hline $32^{\text {ndv }}$ & $\begin{array}{l}\text { Freedom } \\
\text { Fighters }\end{array}$ & 2202 & 1385 & 817 & $37.10 \%$ \\
\hline \multirow{4}{*}{$\begin{array}{l}\text { Total } \\
\text { number of } \\
\text { Quota and } \\
\text { Vacant } \\
\text { posts } \\
2805\end{array}$} & Women & 211 & 201 & 10 & $4.73 \%$ \\
\hline & Tribal & 392 & 94 & 298 & $76.02 \%$ \\
\hline & District & ------ & ------ & ----- & ----- \\
\hline & Disable & ------ & 1 & ----- & ----- \\
\hline & Total & 2805 & 1681 & 1124 & $40.07 \%$ \\
\hline $33^{\mathrm{rd}}$ & $\begin{array}{l}\text { Freedom } \\
\text { Fighters }\end{array}$ & 2702 & 430 & 2272 & $84.08 \%$ \\
\hline \multirow{4}{*}{$\begin{array}{l}\text { Total } \\
\text { number of } \\
\text { Quota is } \\
55 \% \text { of } \\
\text { Vacant } \\
\text { Posts } \\
9008\end{array}$} & Women & 908 & 848 & 60 & $6.62 \%$ \\
\hline & Tribal & 446 & 37 & 409 & $91.70 \%$ \\
\hline & District & 882 & 609 & 273 & $30.95 \%$ \\
\hline & Disable & ----- & 4 & ----- & ---- \\
\hline & Total & 4938 & 1928 & 3010 & $60.95 \%$ \\
\hline
\end{tabular}

Source: Researcher prepared from BPSC's Annual Report 2012 and 2013.

From the Table 2, It is clear that a big amount of quota is unused whereas meritorious graduates are denied. Even, in 32nd BCS that was organized especially for using the reserved 
posts. A great number of posts are remaining empty in freedom fighters and their wards and tribal quota due to the unavailability of qualified candidates. It is seriously retarding the pace of public administration of Bangladesh. On the contrary, the utilization rate of women quota is good because of remarkable women education and empowerment in Bangladesh at present. However, even if women would not get a quota, they could have their position in BCS. Therefore, the question is why and for whom - the high percentage of quota, obviously the answer is pending until now.

\section{Why Merit}

Merit is the ability to do a work efficiently and effectively based on some set criteria specifically for that particular job. No criteria can beat merit for recruitment of personnel in any organization whether public or private. Developed countries of the world like Japan or Singapore recruit public servants based on merit by open and competitive examination. When merit is the core criteria for recruitment in BCS, it would reduce the quota at its minimum. Albeit, a small amount of quota could remain for the most distressed and backward section of the society as said in the Constitution of Bangladesh.

Most importantly, however, using merit principle could ensure equal treatment and open field for all to join BCS and would result delightful performance in public administration. It would prevent brain drain and increase their dedication at work. Hence, positive competition could be seen among them for promotion and better post. In turn, would reduce political intervention and corruption. The final output would be a vibrant and dynamic public administration that could enhance country's growth and development.

\section{Findings or Result of Analysis}

Reviewing the related literature, articles, books and analysis of quantitative data, the study finds some points to ponder such as,

10.1 From Review of Research:

1. Quota dominates the recruitment of Civil Official in Bangladesh, 55\% position of public job is fill by quota and only $45 \%$ by merit

2. Prevailing Quota system is very complex and hard to understand even difficult to implement for BPSC

3. Researchers demand to review the system and recruit maximum public employee based on merit, even some of them ask for the abolition of the quota system

4. The experts argue to have strong political commitment to start meritocratic recruitment and promotion for an efficient administration

5. Investigators also suggest considering the academic record of candidates in recruiting process of BCS

6. Some researchers statistically show that meritocratic recruitment and promotion are positively correlated with good administrative performances 
7. Some authors demand active role of government and BPSC to stop corruption and various irregularities they find after examining the recruitment process

8. In some papers, the study finds the initiatives of administrative reform in Bangladesh and the reasons for the failure of those initiatives like lack of political commitment, corruption, and bureaucratic resistance and so on.

10.2 From Quantitative Analysis:

1. Big portions (47\%) of respondents who are civil servants are of age 31 to 40 years. However, $57.5 \%$ PCS are of age 26 to 28 years

2. Among the interviewee, females count for $35.7 \%$ and $41 \%$ for CS and PCS respectively, and the rest of each group are males

3. The CS group are from various batches of BCS, ranging from 9th batch to 33rd batch

4. Maximum CSs' that is $74.3 \%$ have 1 to 5 years of working experience

5. The common motivating factors for both groups are respect and job security to join $\mathrm{BCS}$, nevertheless, serving nation is also important to them

6. Eighty percent CS says, that they are not fully satisfied with their job, and $97 \%$ respondents are not satisfied with their salary structure at present

7. About $72 \%$ of CS and $44 \%$ PCS opine that the present recruitment system is not sound and requires changes

8. $46.2 \%$ of CS and only $26 \%$ of PCS goes for merit as the first criteria for selection in BCS while a bigger portion of PCS (49\%) wants both merit and quota. Interestingly both groups like to have a consideration of the educational record in the recruitment process. This result can counter the first research question

9. Major segment means $64 \%$ of CS and $80 \%$ of PCS demands to have 60 to 80 percent posts based on merit. While 56\% CS and 49\% PCS chose for 10 to 20 percent quota in the recruitment system

10. Around $57 \%$ of CS and $40 \%$ of PCS thinks that there is a chance of corruption in the recruitment process

11. Exactly $78.5 \%$ CS agrees that merit-based recruitment can prevent the corruption while only $36 \%$ PCS agrees with this statement

12. Key part, about $91 \%$ and $71 \%$ of CS and PCS respectively believes that recruiting brilliant candidates for BCS can bring bright performances in the public administration of Bangladesh. This result answer the third research question too

13. About $73 \%$ of CS and $46 \%$ of PCS thinks that performance should be considered first for promotion of government officials

14. Near about $74 \%$ CS and $14 \%$ PCS think that age limit to allow for appear in the BCS 


\section{Macrothink}

exam is 30 years compare to $10 \% \mathrm{CS}$ and $56 \%$ PCS goes for 35 years

15. For retirement age, the maximum number of CS and PCS suggests for 60 to 65 years

16. In more than $80 \%$, cases both CS and PCS think an official should be honest. However, in above $65 \%$ case they think a civil servant needs to be hardworking

17. The study finds that majority of CS and PCS sought for mix system of public administration is appropriate for Bangladesh. Finally, the greater portion of the respondents wants overall reform of the BCS.

\section{Merit-Based Recruitment in BCS: A Proposed Model}

Figure 2: A proposed Model for Merit-based Recruitment in BCS

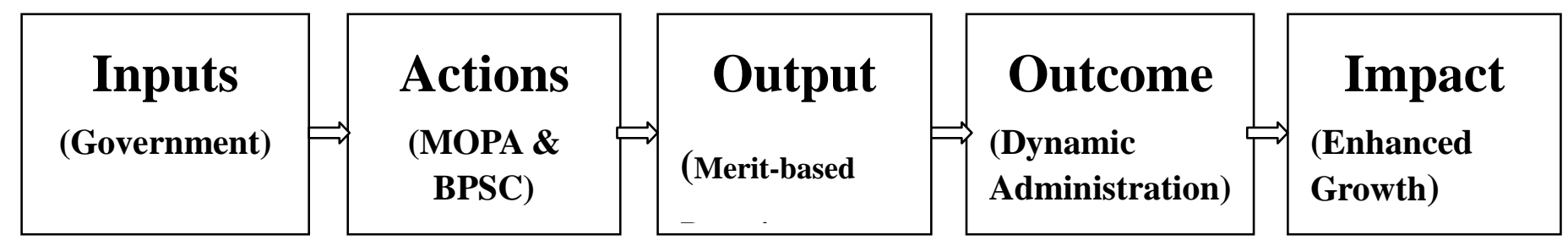

\section{Pre-Requisites or Assumptions}

\section{(Government)}

Researcher prepared

11.1. Working Procedures of the Model:

11.1.1 Assumptions:

The pre-requisite or assumptions are like the base or foundation of this model. The duty of government is to ensure these pre-conditions to make the model run well. The assumptions are,

I. Government ensures equal rights and equal distribution of scarce resources

II. Balance development all over the country ensured

III. Constitutional and legal provision does not hinder the model

IV. Reliable and independent public service commission is working freely

V. Rule of law is working smoothly

VI. Sound and Suitable HRM policy and strategies for public sector is present

VII. Lucrative salary and benefits for civil servants is prevailing 
VIII. Realistic Acts, Rules, Regulations, and their application are available

IX. Proper Recruitment plan with specific time is set

$\mathrm{X}$. No corruption and nepotism is found

XI. No political interference in bureaucracy and

XII. Political commitment for reform.

\subsubsection{Inputs:}

However, along with these conditions some other necessary inputs government has to confirm like, to involve all stakeholders into the process, set required qualification and skills for a particular job, establish Suitable management and implementation policy and control mechanism.

\subsubsection{Actions:}

Finishing the base work, now recruitment activities start. The MOPA and BPSC will play the anchor role here. As mentioned earlier, MOPA gives the BPSC the demand list for recruitment of civil servants. Then, BPSC needs to play active role in,

I. Explicit advertisement and notification of recruitment with full disclosure of information in daily newspapers and websites

II. Open and competitive examination through improved and updated course curricula

III. Accountable and transparent evaluation system that allow challenges

IV. Selection fully based on merit and educational background

V. Publication of full result with all information

11.1.4 Output:

If BPSC can perform their activities accurately and smoothly, it will result a Merit-based recruitment as output. This recruitment system would be the deliverable of this model.

\subsubsection{Outcome:}

With this system, bright and meritorious human resources will join the BCS. The outcome would be a dynamic administration to provide quality and quick service to the general people of the country.

\subsubsection{Impact:}

Finally and ultimately, the impact would be country's sustainable development and enhanced growth through the efficient public administration. 


\section{$\triangle$ Macrothink}

\section{Recommendation}

\subsection{For policy-makers:}

a. Political commitment imbued with patriotism is needed for reforming the public administration of Bangladesh. They can take Singapore or Japan Civil Service as a model for reform

b. Government needs to enact a pragmatic and encompassing Civil Service Act that reflects the expectations of employees of all cadres without any disputes

c. Merit-based recruitment and promotion system in civil service is a must for an efficient and dynamic administration; government should take necessary actions in this regards

d. Because of the constitutional provision a total of $10 \%$ quota for freedom fighters children, tribal and women can be used but for a particular time and then quota needs to eliminate

e. The BCS can use the model proposed for recruitment of government officials

f. The BPSC should initiate an examination system that is open and competitive. The system should judge the real merit not dependent on memorization rather judge the intellectual ability and other interpersonal skills of a person

g. The course curricula of the BCS exam needs updating and as such that can test the scholarly ability of an examinee

h. Along with examining merit by exam, educational background should be considered for recruiting BCS

i. Educational attainment also needs to consider with performance while promoting an employee

j. The Government should set up a permanent pay commission that will update the salary of the public employees time to time taking the economic indicators of our country into consideration.

k. The BPSC must act independently and ensure the recruitment of meritorious as BCS official. BPSC also needs to act to defend the allegations regarding leak of question, corruption in evaluation and viva exam against them to uphold their image

1. Government should take the initiative to stop corruption, nepotism and favoritism from all level of the recruitment process of BCS and ensure exemplary punishment for the accused person

m. Above all, the government should try to guarantee equal rights and opportunity of people of every part of Bangladesh by ensuring balance development that no quota needs in any system. 
12.2 For civil servants:

a. Only meritocratic recruitment cannot prevent corruption rather it needs the honesty, integrity, loyalty and patriotic attitude and ethical behavior of civil servants who can take the country to its desired goals

b. Civil servants should support the administrative reform initiative taken by the government, they should not think only of their cadre or interested groups rather for the whole system.

\subsection{For the academician:}

a. This issue requires more research and examinations, so researchers, experts, and academician should come forward with more analysis and recommendations that can enhance the administrative wheel of our country

b. The proposed model by the study has many scopes for further development; experts can come up with their valuable opinions and improve the standard.

\section{Conclusion}

"Heaven goes by favor; if it went by merit, you would stand out, and your dog would go in" (Mark Twain) $^{\mathrm{vi}}$.

The great scholar and writer of American literature Mark Twain (1835-1910); the world knows him for his humor. In the quote above, he just makes fun and speaks the reality of the world. Even after so many years his statement works, Bangladesh Public Service as an example. If we consider, Bangladesh Civil Service (BCS) as the heaven then merit cannot ensure ones' position into the service of the republic rather quota or preserve post can. The Greater portion of civil servants in Bangladesh is entering into the service with blessings of the quota system. Consequently, not only denying the talented people to the BCS, but also producing poor quality services and results for the state.

Against this backdrop, the study tried to know the idea and view of present and future civil servants. However, the study was confined with the first-class official only not all classes of BCS. One limitation may be the working civil servants cannot speak openly against the system. As a result, a little gap may remain in their opinions and results of the study. Moreover, despite the respondents are selected randomly, they might be biased to merit or quota. The study had no intention to find out their biased tendency. In addition, the model will work if the assumptions work properly. Therefore, further advancement of the model is possible, and experts should come up with their idea to add value to the study.

Nonetheless, the study tries to bring the ideas and attitudes from the victims of the system and proposes a model for recruitment based on merit. A merit-based recruitment and promotion system is necessary to have a vibrant, dynamic and efficient administration, which can materialize the vision of the nation. The study can help in finding the way to build such a system. It is the government to decide - Now or Never. 


\section{Macrothink}

\section{Acknowledgement:}

The author of the paper expresses heartfelt gratitude and acknowledges respectfully the guidance, advice and supervision of Professor Kiyoshi HAMASHIMA, the faculty of Graduate School of Economics, Yamaguchi University. Professor's overall direction and support help the author tremendously to complete the study and prepare the manuscript. The writer of the paper will always remain grateful to the professor.

\section{References:}

Alvarado, L. A. (2010). Dispelling the meritocracy myth: Lessons for higher education and student affairs educators. The Vermont Connection, 31, 10-20.

Aswathappa, K. (2005). Human resource and personnel management. Tata McGraw-Hill Education.

Biswas, R. (2013, July 25). Merit should not be superseded by quotas. The Daily Independent.

BPSC. (2012). Annual Report:Dhaka, Bangladesh Government Press.

BPSC. (2013). Annual Report:Dhaka, Bangladesh Government Press.

Cardona, F. (2002). Scope of civil services in European countries. OECD, Paris, http://www. oecd. org/dataoecd/44/33, 1, 850438 .

Chalam, K. S. (Ed.). (2014). SAGE: Governance in South Asia: State of the Civil Services: K $\mathrm{S}$

Daugher, M. (2014). Michael Dugher speech on the Civil Service | The Institute for Government. $\quad$ Retrieved March 24, 2015, from http://www.instituteforgovernment.org.uk/news/latest/michael-dugher-speech-civil-service

Government of Bangladesh, 2014. The Constitution of the people's republic of Bangladesh (amended till - 10 November, 2014). Dhaka: Ministry of Law, Justice and Parliamentary Affairs.

Haque, A. (2006, July 17). By the Numbers - Civil Service Shame. The Daily Star.

Jahan, F. (2006). Public administration in Bangladesh. Centre for Governance Studies Working Paper Series, 1.

Jahan, M. (2012). Recruitment and Selection Process in Bangladesh Civil Service: A Critical Overview. Public Policy and Administration Research, 2(5), 29-36.

Khan, A. A. (2010). Friendly fires, humpty dumpty disorder, and other essays: reflections on economy and governance in Bangladesh. Dhaka: University Press.

Khan, M. M. (2009). From Government to Governance: Expending the Horizon of Public Administration to Public Management (1ST edition). The University Press Limited. 


\section{Macrothink}

Journal of Public Administration and Governance ISSN 2161-7104 2015, Vol. 5, No. 3

McCrudden, C. (1998). Merit principles. Oxford Journal of Legal Studies, 18(4), 543-579.

McCourt, W. (2007). The Merit system and integrity in the public service. Manchester: Inst. for Development Policy and Management. Retrieved from http://www.sed.manchester.ac.uk/idpm/research/publications/wp/depp/documents/depp_wp20 .pdf

MOPA. (2013). Statistics of civil officers and staffs : Dhaka, Bangladesh Government Press

Obaidullah, A. T. M. (1999). Bangladesh Public Administration: Study of Major Reforms, Constraints and Strategies. Academic Publishers (BD).

Pruthi, R. K. (Ed.) (2005). Paradigms of Public Administration and Civil Services > Pruthi, Raj Kumar | Saujanya Books. Retrieved March 19, 2015, from http://www.saujanyabooks.com/details.aspx?id=28843

Rabbi, M. F., \& As-Saber, S. N. (2012). From Ideology to the Consolidation of Regimes: What Drives Civil Service Reforms in Bangladesh. Journal of Administration \& Governance JOAAG, 7(2), 19-35.

Raadschelders, J. C., Toonen, T. A., \& Meer, F. M. (Eds.). (2007). The civil service in the 21st century: comparative perspectives. Palgrave Macmillan.

Rao, S. (2013). Civil Service Reform: Topic Guide. Birmingham: GSDRC, University of Birmingham.

Rauch, J. E., \& Evans, P. B. (2000). Bureaucratic structure and bureaucratic performance in less developed countries. Journal of public economics, 75(1), 49-71.

Reynolds, J., \& Xian, H. (2014). Perceptions of meritocracy in the land of opportunity. Research in Social Stratification and Mobility, 36, 121-137.

Sarker, A. E. (2004). Administrative reform in Bangladesh: three decades of failure. International Public Management Journal, 7(3), 365.

Siddiqui, K. (1996). Towards good governance in Bangladesh: Fifty unpleasant essays. University Press Limited.

Suk Kim, P., \& Monem, M. (2009). Civil service reform in Bangladesh: all play but hardly any work. Asia Pacific Journal of Public Administration, 31(1), 57-70.

Wahhab, M. A. (2009, December). Civil Service Recruitment Policy in Bangladesh; A Critical Analysis. In Paper submitted for NAPSIPAG International Conference, held on (pp. 11-13).

Werther, W. B., \& Davis, K. (1996). Human Resource \& Personnel Management, 5th. MacGraw-Hill International Edition.

Yesmin, N. (2010). Quota system in Bangladesh civil service: an appraisal (Doctoral dissertation, BRAC University). 


\section{Macrothink}

Journal of Public Administration and Governance

ISSN 2161-7104

2015, Vol. 5, No. 3

Zahid, S. (2013, August 16). Quota in Public Servie: To abolish or not to abolish. The Daily Financial Express.

\section{Glossary:}

\footnotetext{
Hamid Ansari is the vice president of India since 11 August 2007.

ii "Cadre is the distinct functional sub division of the government bureaucracy" (Jahan, 2012)

iii PCS are the fresh graduates trying to join BCS after graduation

iv After applying the quota for freedom fighters and wards, women, and tribal, if there are any vacant posts, and then $1 \%$ of that is given as disable quota. So it is not preserved initially.

$\checkmark$ The $32^{\text {nd }}$ BCS is a special examination conducted only for the unfulfilled reserved posts of freedom fighters, women and tribal in the posts of technical and professional cadres

vi ("Quote by Mark Twain: 'Heaven goes by favor. If it went by merit, you ...,"” n.d.)
} 